\title{
Light-handed regulation: the case of the Tasmanian Forest Practices System
}

\author{
Dr Robyn Hollander ${ }^{1}$ \\ Department of Politic and Public Policy, Griffith University \\ Phone: (07) 3735 7652; Fax: (07) 3735 7737; Email: R.Hollander@griffith.edu.au
}

\begin{abstract}
In recent years, governments have shifted away from traditional command and control regulation in favour of more flexible approaches built on notions of trust and co-operation between the regulator and the regulated. Such approaches recognise the limitations of traditional methods in terms of both cost and efficacy, and rather than adopting a constabulary stance, attempt to engage with industry in a constructive way utilising economic incentives and the desire of most firms to 'do the right thing' most of the time. These 'light-handed' approaches work best when public and private interests converge, the degree of risk is low, and there is scope for third party oversight.

The Tasmanian government has adopted this light-handed approach in its regulation of logging in native forests. Its Forest Practices System is built on industry co-operation where regulation is conceptualised as a partnership between government and business. This paper assesses the effectiveness of such an approach. It finds that the System has the capacity to overcome some of the hurdles to effective regulation, such as information asymmetry and industry opposition, but is limited in other respects because of a lack of transparency, the absence of third party oversight, the nature of the risk and the potential mismatch between public and private interests.
\end{abstract}

${ }^{1}$ I would like to thank my colleague Dr Giorel Curran, and two reviewers for their helpful comments on earlier versions of this paper. 


\section{Introduction}

Regulation is best understood as a response to the incapacity of private law and private markets to adequately protect the public interest (Ogus 1994). Over the course of the Twentieth Century, it has become a prominent part of the state's armoury as governments' have stepped back for more direct forms of engagement (Eisner 2003). However, the state's growing use of regulation as a policy instrument has not escaped scrutiny and what in the past was construed as market failure, is increasingly seen as state failure (Daneke 2001:517). In response, governments have progressively turned away from the traditional command and control approaches which served them in the past in favour of more innovative regulatory instruments. Some of these new instruments, such as firm or industry based self-regulation or market based mechanisms, are beyond direct state control. Others retain the state as a key player but in a collaborative, rather than punitive, role. Instead of the old constabulary approach, regulators have embraced more flexible, light-handed approaches characterised by notions of co-operation and shared goals. One of the things which characterises contemporary regulatory theory and practice is a rejection of a 'one size fits all' approach in favour of more nuanced regulatory solutions which take a range of factors including the nature of the industry, the degree of risk, and the capacity for third party engagement into account. The challenge now facing regulators is to find the regulatory approach which both engages industry and satisfies public interest demands.

In Australia, State governments have used new regulatory instruments in management of their forest resources. As part of the Regional Forest Agreement process, they committed themselves to developing appropriate regulatory frameworks for managing their forests in ecologically sustainable ways. While most jurisdictions provide opportunity for those engaged in logging some input into the regulatory system, the Tasmanian system is the most highly developed (Wilkinson 1999). It is characterised by close relationships, or partnerships, between regulator and regulated who play a considerable role in the establishing, monitoring and enforcing the regulatory framework (Wilkinson 2001). Given Tasmania's leadership in the area, it is important to assess the capacity of co-operative model built on notions of trust and partnership to deliver satisfactory regulatory outcomes all round.

The paper begins with an overview of developments in regulatory theory focusing in particular flexible or light-handed approaches and their application in dealing with environmental problems. It also looks at the variables which impact on the effectiveness of the different forms of co-operatively 
based regulation. The second section summarises the key features of the Tasmanian Forest Practices System and the third section evaluates the model in light of the variables identified in the first section. In other words, it assesses the limitations on the Forest Practices System as a regulatory strategy for securing the goal of ecologically sustainable forest management. Finally, the paper briefly discusses the changes proposed at the end of 2004.

\section{Approaches to regulation}

Regulation has been variously characterised with definitions ranging from broad sociological notions to narrower conceptions which place the state at the epicentre (Baldwin, et al. 1998:3-4; see also Ogus 1994:1). However, even within the narrower definition, an array of options exists. Jackson (1997:123) adopts a tripartite typology of regulatory regimes - external, or state centred regulation; self, or producer, regulation; and mixed regimes which incorporate elements of both external and selfregulation. Under an external regime, independent authorities take responsibility establishing, maintaining and enforcing the regulatory framework; self regulation involves the producers themselves undertaking these key roles; while under a mixed regime, responsibilities are shared.

However, many reject such sharply defined categorisation because it fails to capture both the multiplicity of possible governance arrangements and the range of instruments available. For example Sinclair (1997) and Ogus (1995) reject the clear cut categorisation of self regulation. As Sinclair (1997: 532-3) points out, the term encompasses a range of regulatory forms from voluntary firm or industry level self regulation, with no state intervention; to enforced industry self regulation, where a industry is directed to design and implement a code of practice; to partial self regulation, where industry and government share regulatory responsibility. Hence, self regulation is more accurately understood as a mixed regime involving varying degrees of state compulsion, regulatory flexibility, and industry engagement.

Nor is the notion of external regulation as clear cut as it first seems. While most examples are state centred, even these vary considerably in terms of their structural independence from government, the relationships they enjoy with the regulated, and the regulatory strategies they adopt. As Halligan and Wettenhall (1990) point out, state instrumentalities come in a variety of shapes and sizes. Some, like government departments are staffed by public employees and directly connected to the political executive, but others, the statutory authorities, can enjoy considerable independence from government. With their boards may be dominated by industry players, and their staff drawn from 
the industry sector, they can operated at arms' length from government. In such circumstances, the line between the regulator and the regulated can be somewhat fuzzy. This was particularly true in the past when it was common to combine regulatory functions and service provision within the same organisation. Recent trends in public sector reform have demanded a formal separation between production and regulatory functions (see for example National Competition Council 1998: 18-19).

Even in situations where the regulated and the regulators are formally separate, regulators may nevertheless be 'captured' by the regulated. The concept of regulatory capture has a long tradition in the North American literature within both the functionalist and public choice literatures (Moran 2002: 393-394). Put simplify, regulatory capture is characterised by a situation where the regulators act in the interests of the regulated at the expense of the community at large (Balwin, et al. 1998: 10; Mitnick 1980: 208). This phenomena is accentuated in a user pays environment where the regulated fund the regulatory system (Sharp 1996). In the British case, Moran (2001: 423-424) rejects the somewhat simplistic notion of capture, arguing that the more organic, long lasting interactions built on shared goals and perceptions between the regulator and the regulated are more accurately understood as symbiosis. Concepts of capture and symbiosis suggest that relationships and regulatory strategies rather than institutional arrangements are of central significance in understanding regulation.

The themes of relationships and strategies are taken up by Ayres and Braithwaite's 1992 work on what they term 'responsive regulation' (Ayres and Braithwaite 1992). Responsive regulation is their answer to the traditional command and control approach whereby 'Government literally commands industry to meet specific ... standards ... and controls its behaviour through the threat of negative sanctions' (Sinclair 1997: 534). Although command and control may offer the universality, anti corruptibility, and strong legal position characteristic of black letter law (Sparrow 2000: 37), it is ill suited to meet the contemporary challenges of political acceptability, effectiveness, and efficiency. Moreover, heavy-handed, inflexible regulatory approaches are likely to breed dissent and noncompliance. In a climate of mutual suspicion, regulators and regulated are locked in a contest of wits with the latter searching for the loopholes the former are trying to close off. However, in Ayres and Braithwaite's world view, a firm is not an unscrupulous, calculating entity determined to will break the law unless the anticipated penalties exceed the costs of compliance, but a "political citizen" who is ordinarily inclined to comply out of belief in the law as well as long-term self-interest' (Hill and Stewart 1998: 2). From this starting point, Ayres and Braithwaite develop a regulatory schema which employs hierarchies, or pyramids, of both intervention and enforcement. Good corporate citizens can 
expect light-handed regulation and minor transgressions light penalties, but repeated and major transgressions will attract intrusive external interventions and oppressive penalties (Ayres and Braithwaite 1992: 35-40).

This tailored approach also characterises Gunningham and Grabosky's 'smart regulation'. Gunningham and Grabosky (1998) expand the notion of regulation beyond the standard rule based notion to encompass a range of instruments from education and training to market mechanisms. They argue that effective regulation involves a mix of elements customised to meet the specific characteristics of the industry and the regulatory problem. Hence, governments need to be guided by the circumstances in selecting the most appropriate approach. Heavy-handed regulation is best suited to situations where the chance of adverse outcomes is high and the consequences severe. Such a case might call for licensing, a detailed prescriptive code with close monitoring, and heavy penalties for non-compliance (Gunningham and Sinclair 2002: 32). A lighter hand is more appropriate where risks are low and the consequences comparatively minor. Regulation in these circumstances might rest on a public scrutiny and consumer preference. Each regulatory problem presents with a distinctive set of variables. Factors, such as the nature of the problem, economic and cultural characteristics of the industry and its relationship with third parties may all be relevant. This model of regulation recommends that the approach match the circumstances, the compliance burden match the risk, and the enforcement mechanisms are realistic and effective.

These ideas have been important in area of environmental regulation. Indeed, the field was the focus of Gunningham and Grabosky's ground-breaking work. Over the years, environmental policy makers have utilised a wide range of regulatory approaches from traditional command and control regulation (used to restrict air emissions, effluent flows, and run-offs, and so on); economic prompts (devised to increase the costs for higher polluting plants, or rationalise water use); knowledge based instruments (the development of pollution inventories and product information in response to community and consumer demands for information); and voluntary agreements and codes of practice (to reduce the cost and increase the effectiveness of resource harvesting activities). But how do policy makers determine the most appropriate mix? It is to this question we now turn.

According to Fiorino (2001), public policy is best understood as a learning response to policy problems, and hence the way we understand these problems is important in determining the regulatory approach. Fiorino (2001) argues that command and control strategies correspond to perceptions of the environment as a set of technical problems while more conceptual understandings 
derived from systems theory lend themselves to the use of alternative market based or educational instruments. The most recent understandings built on social learning, emphasis relationships as the key to solving policy problems and, hence lend themselves to a responsive regulatory approach.

The nature of the problem is important in another way. Francis (1993: 11) argues that regulation needs to be understood as a response to risk. However, as Moran (2002: 407) observes, risk emerges in the regulatory literature in different ways - as a cataclysm, the result of industrialisation; as an unavoidable market phenomena, the result of firm behaviour; or as a cultural construction driven by perceptions and politics. Irrespective of how it is understood, different levels of risk demand different state responses. In situations where risk to the public interest is acute, governments need to take a hands-on approach but where risk is comparatively minor, government can allow industry significant flexibility. But how do we assess the level of risk? Even if we understand it as an objective phenomenon, judgements about the most appropriate level of state regulatory intervention rest on the existing state of scientific knowledge. Such judgements presuppose a clear understanding of the potential for adverse outcomes. This knowledge is often lacking in environmental policy areas especially when considering complex issues like biodiversity, a fact recognised in the precautionary principle. In relation to forests, for example, McDonald and Lane (2002: 648) argue that we have a relatively underdeveloped understanding of the limits of their resilience. In some ways, the problem is more testing when risk is conceptualised as a cultural phenomena because in such cases regulation has to satisfy the more amorphous political and social demands.

A convergence of interests is another variable that affects the appropriate level of regulation. Lighthanded regulation is likely to prove most effective in situations where the private interests of industry coincide with public interest (Sinclair 1997: 6; Gunningham and Rees 1997: 390). In the environmental area, it is most effective when environmentally responsible behaviour equates with good business. This convergence can occur where, for example, processes designed to improve environmental outcomes are also cost effective or provide a producer with a market advantage.

Industry characteristics, such as the rate of technological change and the number and size of firms, are also important. For example, industries experiencing rapid technological change are better able to capitalise on the flexibility associated with light-handed regulation to introduce innovative strategies to meet regulatory standards (Sinclair 1997: 542). This style of regulation is also likely to be more effective in industry which is dominated by a small number of large firms because large firms have 
the resources to develop and maintain appropriate standards (Sinclair 1997: 542; see also Gunningham and Sinclair, 2002).

The role of third parties in the regulatory arena is another of the variables which help determine the appropriateness of a light-handed approach. Third parties, by identifying and reporting transgressions, can act as powerful monitoring forces. In this, they can act as 'agents of informal social control' (Gunningham and Grabosky 1998: 93). Some third parties have a commercial relationship with the regulated business and this positions them for a monitoring role. On the input side, investors, financial institutions, suppliers and trade unions all have the potential to observe practices, and in some cases, discipline transgressors. On the output side, purchasers or consumers can act as very powerful monitoring agents especially with effective complaints mechanisms in place (Gunningham and Grabosky 1998: 108-113). For example Carmin et al. (2003: 539) point to the importance of purchasers in promoting the spread of Voluntary Environmental Programs.

Other third parties lack such a direct connection, but nevertheless can play a role in establishing, monitoring and enforcing the regulatory framework, reinforcing its legitimacy and providing independent oversight thereby guarding against corruption and capture (Beierle and Cayford 2002; Ayres and Braithwaite 1992: 56). However, Weber (1998) argues that trust between the various stakeholders, although the key to successful regulatory collaboration, is often absent in the sometimes acrimonious relationships between industry and conservationists. Moreover, Seidenfeld (2000: 26) doubts the possibility of widespread third party collaboration unless radical 'fringe groups', uncommitted to problem resolution can excluded. The effectiveness of third party oversight also depends on the availability of information. It is often difficult for other groups, the media, or the public at large to access the insights necessary to participate. Monitoring, for example, is difficult where activity occurs beyond the public gaze. For example, Gunningham and Grabosky (1998: 290) suggest that the low visibility of many agricultural practices reduces the risk of detection and penalties for non compliance. Moreover, the 'sanctity' of private property provides added protection from prying eyes.

To sum up, this section has shown that the capacity of light-handed regulatory system to deliver public interest outcomes depends on a range of context specific variables. This means that any regulatory system cannot be evaluated according to any set of principles but needs to be considered in its specific context, a task now taken up by this paper. 


\section{The Tasmanian Forest Practices System}

The Tasmanian Forest Practices System provides a good example of a light-handed regulatory system. Principles of constructive engagement between state and industry are evident in both its institutional composition and in its regulatory practices. This section traces that commitment by looking at first institutional structures and then the design and practice of the regulatory system.

The Forest Practices Board occupies a pivotal role in the system. On the one hand, it is charged with the task of providing Government with policy advice, and on the other, has responsibility for overseeing the operation of the regulatory framework. The Board, whose membership is set down in legislation, has traditionally been dominated by industry insiders. Before 1999, it had only four members. One was the director of Private Forests Tasmania, a statutory body responsible for assisting forestry activities in the private sector. Two positions were drawn from what was to become Forestry Tasmania, the entity charged with managing forestry in crown forests - the CEO and another of its directors. The final member of the complement was the secretary of the department with carriage of the State's Environmental Management legislation - Primary Industries, Water and the Environment (Forest Practices Act 1985 Tas. s.4A1a).

The Board's composition was altered following an independent review undertaken in 1997 as part of the Regional Forest Agreement process. The review was critical of the close relationship between the Board and Forestry Tasmania, noting both the overlap in personnel and the intertwining of regulatory and business functions. It recommended that these functions be formally separated, and changes made to the make-up of the Board (Independent Expert Advisory Group 1997). The changes that followed did provide for a functional separation, although both bodies remained under the stewardship of the powerful Department of Infrastructure, Energy and Resources. The government also expanded the Board. The new five member Board retains three of the four previous positions. The CEO of Forestry Tasmania was removed, and positions for a local government nominee representing a forestry municipality and appointee with experience in timber harvesting or processing were added (Forest Practices Act 1985 Tas s.4A).

The changes were not met with universal acclaim when presented to the Parliament in 1999. Green member, Peg Putt pointed to the absence of conservationists and other forest users such as apiarists and tourist operators. Liberal opposition leader Rene Hidding worried that the interests of agroforesters would be neglected, and fretted that the local government position could be vulnerable 
to a green assault in local government elections. However, the Minister, Paul Lennon assured Mr Hidding that he, as Minister, controlled the local government appointment process, and that ample provision would be made for private sector representation on other associated bodies (Legislative Assembly Parliament of Tasmania 1999: 40-107).

The Forest Practices Advisory Council is one of these bodies. The Council provides a formal channel for expert advice and stakeholder input. The composition of the seven member Council is strikingly similar to that of the Board. The Board's chair is joined by representatives drawn from the bureaucracy, Private Forests Tasmania, and Forestry Tasmania; and three Ministerial appointees with practical expertise in timber harvesting and processing, forest conservation, and tree growing on private land (FPB 2003: 11). The Forest Practices Tribunal, the body which considered appeals against Board decisions, provides another arena for industry input. The selection criteria for Tribunal membership emphasises practical knowledge in relevant areas with places reserved for those with expertise in forestry, farming and land management but also in the law and conservation science. Industry involvement was paramount here as well. Looking through the 2003 list of members, we see a degree of organisational overlap with associated organisations, such as Private Forests Tasmania, and links with the Forest Practices Board. For example, Bert Witte, an appointee with 'sound and practical knowledge of forestry, road construction in forests, and harvesting of timber', was a former Chief Forest Practices Officer with the Board (Forest Practices Board 2003: 16).

Industry engagement was central to the design and revision of the Forest Practices Code, which provides the framework for forestry in Tasmania. The Code sets down standards for the management of forest activities including the establishment of forest plantations and timber harvesting. The Forest Practices Act, 1985 Tas. s32 mandates that key industry stakeholders - Private Forests Tasmania, Forestry Tasmania and the Forest Practices Advisory Council - be involved in changes to the code. The Act also provided for more general consultation. Such consultation occurred prior to the revisions in 2000 although many of the concerns expressed were found to be beyond the scope of the code itself (Forest Practices Board 2002).

The commitment to co-operation underpins the design of the regulatory mechanisms and is embodied in the critical role of Forest Practices Officers. These Officers are appointed and trained by the Board, empowered by statute (Forest Practices Act 1985 s40) and generally employed directly by 
organisations engaged in logging or as consultants. ${ }^{2}$ They have first line responsibility for key elements of the regulatory system - the Forest Practice Plans and the Forest Practices Code. Forest Practice Plans are required for harvesting and planting operations carried out on private or Crown land. These plans outline the proposed activities, their impact, and management strategies. They need to comply with the Forest Practices Code which sets out environmental standards and provides guidelines for achieving those standards. (Forest Practices Board 2000: 2). The Plans are certified by an authorised Forest Practices Officer before operations can commence (Forest Practices Board 2000: 5). The Plans themselves are most commonly prepared by Forest Practices Officers although this is not a legal requirement and they can be prepared by anyone. However, it is in the industry's interest to use Forest Practices Officers because as the Board points out, '[they] have the skills and knowledge necessary to ensure that plans achieve the high standard necessary for approval' (Forest Practices Board 2003: 32). Forest Practices Officers are then responsible for ensuring that forestry operations adhere to the Plan and comply with the Code. On completion, selected Forest Practices Officers prepare certificates of compliance which are lodged with the Board (Forest Practices Board 2003: 17). These documents confirm that activity has occurred as planned and outlines any deviations.

Forest Practices Officers are important agents for monitoring and enforcement of the Forest Practices Code for the duration of the plan and beyond. They have the power to issue directions and are encouraged to undertake periodic onsite inspections during operations to ensure that problems are addressed in 'a timely manner' (Forest Practices Board 2003: 13). Forest Practices Officers can also order that corrective action be undertaken before they issue the certificate of compliance. Forest Practices Officers act as the preferred agents for investigating complaints regarding forestry operations and undertake the task 'where ever possible' leaving more serious breaches to the Board and the Director of Public Prosecutions (Forest Practices Board 2003: 28). Forest Practices Officers also participate in the Board's independent audit of Forest Practices Plans. Annual audits are required by legislation and are undertaken to assess the effectiveness of the system as a whole. The 2002/3 audit was undertaken by two industry Forest Practices Officers and covered about $17 \%$ of all plans. The Board stressed that these audits were not to identify breaches of the code per se but rather aimed to assess the efficacy of the system as a whole (Forest Practices Board 2003: 20).

${ }^{2}$ In 2003 Forestry Tasmania was the largest employer of Forest Practices Officers (78), followed by 'industry' (64), independent consultants (32), Forest Practices Board (3) and Private Forests Tasmania (8) (Forest Practices Board 2003:29). 
Enforcement strategies used in Tasmania are a classic example of Ayres and Braithwaite's enforcement pyramid. Their pyramid emphasises the use of education and persuasion to deal with the majority of transgressions, with warnings and corrective action as second line responses. The 'big stick' of fines and prosecutions is reserved for more serious and persistent transgressions. The Board emphasises training and education as the basic building block of compliance. The second line of enforcement consisted of formal compliance notices issued by Forest Practices Officers. These notices, in the first instance, remind loggers of their obligations and, in the second, require that work cease and restitution occur where necessary. These notices are not issued frequently. In 2002/3, for example, only 30 notices were issued which constitutes a relatively small number considering the scale of operations; in the same period, 940 forest practice plans were approved and 1111 compliance certificates lodged. The 'big stick' of fines and prosecutions was waved even more infrequently. In 2002/3, the Board imposed only seven fines. Of these, four were for relatively small sums and only three involved substantial amounts. The largest was for $\$ 50,000$ and the firm, Gunns Ltd, had to also meet the cost of substantial remedial work. There were no prosecutions (Forest Practices Board 2003: 27-8).

The Tasmanian Forest Practices System clear example of light-handed, or co-operative regulation. Industry is a significant player in the design and implementation of the system and takes primary responsibility for monitoring and enforcement through the Forest Practices Officers, the Board and the Tribunal. The state is well represented institutionally on both the Board and the Council, albeit through its business arms, Private Forests Tasmania and Forestry Tasmania, and not as a representative of broader public interests. The Forest Practices Board has a very small complement of long term staff who are primarily engaged in research and advice. Most of the system's workforce is employed either directly or indirectly by industry. Government's most important contribution is to empower the system through delegation of state power to the Forest Practices Officers, the Board and the Tribunal. This means that the Tasmanian system is best understood as a form of light-handed regulation where state, in its supervisory capacity, acts in close collaboration with business interests, both public and private. We now need to assess whether the preconditions existed for this lighthanded approach.

\section{The Tasmanian Forest Practices System in Context}

In many ways, a light-handed approach is ideally suited to an industry characterised by fragmentation, information asymmetry, and a culture of resistance. This was the stance adopted the 
Chief Forest Practices Officer, Graeme Wilkinson (2001: 2) who argues the approach adopted by the Tasmanian government was both appropriate and effective because it addressed key regulatory challenges in a way that traditional command and control strategies could not. They invariably descended into a costly ‘spiral of tightening regulation and litigation'; were administratively cumbersome and inefficient; and typically promoted only minimum standards. By contrast, Wilkinson maintains (2001) co-operative regulation encouraged continuous improvement and hence had the potential to deliver outcomes which far exceed minimum standards. This potential is reinforced by the general duty of care provisions of the Forest Practices Code (Forest Practices Board 2000: 52) which requires landowners to protect soil and water resources, and withhold $5 \%$ of forest areas in order to conserve natural and cultural values. It is also cost effective because industry carried the bulk of cost of operating the system. In 200/4, the Board estimated that industry contributed about $\$ 7 \mathrm{~m}$ through the preparation, supervision and certification of forest practice plans, and the training and employment of Forest Practices Officers, and contributed over \$1m towards the Board's research and advisory work. In the same period, the Board spent $\$ 646,000$ of public moneys, primarily on administration and investigation (Forest Practices Board 2004: 44-5).

Moreover, the approach also suits the culture of an industry is characterised by significant numbers of private land owners and significant information asymmetry. Without the co-operation of public and private landholders, the detailed information necessary for the effective management of logging operations is simply not available. The Tasmanian system draws private land holders into the regulatory net by recognising 'private timber reserves'. These reserves fall under the Forest Practices Act and, as a consequence, are protected from changes in local zoning requirements. The Act facilitates the establishment of these reserves by limiting opportunities for opposing applications. The right to comment on applications is restricted to public authorities and parties with an ownership interest in the property, giving neighbours very limited opportunities (Forest Practices Act s78). By 2002/3, the Board had approved over 1,4000 applications covering over 400,000 hectares of forest which constituted about 38\% of forest held in private hands (Forest Practices Board 2004: 8).

Although the Forest Practices System may have succeeded in bringing industry on board, we also need to consider whether the regulatory framework was suited to achieving other regulatory goals such the minimisation of externalities, and the protection of community interest and intergenerational equity. To do this we need to look at the contextual elements which impact on the effectiveness of such regulatory approaches. Sinclair (1997) argues that if regulation was to be effective, it needs to 
address the specifics of the particular regulatory challenge. He identifies several key variables which affect the success of a regulatory model. While his focus is on self-regulation, the elasticity of his definition of self-regulation makes his criteria applicable more broadly. This paper now assesses the fit between the regulatory approach adopted in the Tasmanian and the environment in which the industry operated by focusing on key variables such as the regulatory problem, the congruence between public and private interests, the nature of the industry, and the scope for third party engagement.

The nature of the regulatory problem is an important consideration when evaluating a regulatory system. Francis (1993: 11-17) suggests that regulation is concerned with minimising risk. The implication of this is that in high risk situations where there is a realistic chance of irreversible consequences, a more interventionist style of regulation is appropriate. However, this is more complicated than it first seems; as Moran (2002:507) points out, risk can be understood in several ways - as a consequence of market pressures, as a calamity, and as cultural construction - and a regulatory regime needs to address all of these to gain and maintain public confidence. The Forest Practices System is well suited to dealing with risk if it is understood as a challenge of modifying, or moderating, businesses' pursuit of profit but it is less well adapted to address risk in its other guises. Working, as it does, within a micro management frame, it sidesteps any unknowns about biodiversity and the long term viability of ecological systems because it works within established scientific knowledge. Moreover, its positivist foundations mean that it does not engage with risk as a cultural construction, and is ill adapted to control, or prevent, activities which, may be insignificant from a scientific perspective, but are perceived as high risk. This means that the System's failure to protect 'El Grande', one of Australia's largest trees, killed by a regeneration burn-off (Darby, 2003: 3; Paine, 2003: 3), although insignificant in terms of scale, was nevertheless significant because of public perceptions. Forestry Tasmania recognises the importance of these large trees in its 'giant trees policy' (Forestry Tasmania 2002).

Gunningham and Rees (1997: 389-90) argue that light-handed regulation is best suited to situations where there is a coincidence of public and private interest thereby creating a situation where it makes good business sense to behave in ways which meet community goals. According to Wilkinson (1999: 3), such a situation prevails in the Tasmanian forests. He suggests that it is a foolish logger who destroys the resource for short term gain and in the process denies themselves a long term future in the industry. Hence, it is in loggers' self interest to conserve soil and water resources and ensure the 
regeneration of the resource, albeit potentially in a different form. However, ensuring the future of the industry is just one of the goals of ecologically sustainable forest management. Another is the protection of biodiversity and areas of high conservation value but it is more difficult to identify an easy concurrence of public and private interest around such goals.

While private and public interests might not come together in an obvious way, industry can nevertheless have an interest in retaining a high degree of self management. This can provide businesses with an incentive to submit to abide by the regulatory framework in order to avert the danger of more heavy handed government intervention. However, the effectiveness of this as an incentive depends, in part, on the risk of being caught out, a factor considered below. It also depends on the behaviour of other industry players, and the structure of the industry.

Sinclair (1997: 542) argues that light-handed regulation is most appropriate for industries where there are a small number of players operating in an environment of rapid technological change and that large businesses can more effectively regulate their own behaviour compared to their smaller counterparts. In the Tasmanian case, this generalisation has been borne out by the Forest Practices Board's own findings. Its 2002/3 audit of compliance found that large businesses performed better than smaller operations across a number of criteria. Thus, while performance was generally above established criteria for operations undertaken in state forests and by large corporate holdings, the Board observed 'substantially poorer standard of operations by independent operators on private property' (Forest Practices Board 2003: 23). These independent owners constituted a considerable share of the industry. According to the Australian Bureau of Statistics (2004), 16\% of private forests were owned by large industrial concerns and the balance was in the hands of individual private owners. Moreover, much of the work is undertaken by independent logging contractors. For example, in 2004 Forest Enterprises, a large concern, used about 180 independent contractors in its operations across Tasmania, Victoria and NSW (Forest Enterprises 2004). Wilkinson (1999: 5) claimed that the relationship between large firms and smaller contractors 'consistently resulted in better standards of forest practices than those achieved by contractors who work independently of the large forest companies' because the former took responsibility for regulatory oversight. However, a survey of recent prosecutions suggested that violations of the Code still occurred. In 2002/3, both Gunns Ltd and Forestry Tasmania were fined substantial amounts for breaches of the Code involving contractors (Forest Practices Board 2003: 27).

The success of any regulatory system rests, in large part, on the effectiveness of monitoring and 
enforcement provisions. In the Tasmanian case, much of this core responsibility lies with the Forest Practices Officers. These Officers occupy a pivotal role - they approve plans, and oversee and certify operations. They also investigate complaints. The integrity of the system rests on their professionalism and the specialist training provided by the Board on one hand, and the Board's power to discipline them on the other. Given the vast majority of Forest Practices Officers are not Board employees, the Board's disciplinary powers appear somewhat limited. In 2002/3 for example, the Board took action against six Forest Practices Officers for unsatisfactory performance in relation to the preparation of Plans; three received formal warnings, two were suspended for a month and one had his cultural accreditation temporarily revoked (Forest Practices Board 2003: 30). Appeals to professionalism and disciplinary capacity of the Board must be balanced against the employment opportunities open to specialised professionals in a comparatively small industry. According to the recent Senate report (2004: 137), the system places Forest Practices Officers in the 'invidious position when it comes to enforcing the Forest Practices Code against the interests of their employers'.

The financial dependence that characterises the relationship between the industry and Forest Practices Officers extends to the system itself which essentially operates on a user pays principle. The Board depends on businesses for about $63 \%$ of its annual revenue with deriving the remaining $37 \%$ from consolidated revenue (Forest Practices Board 2004: 46). Hence, its continued financial viability rests largely with those engaged in logging. Theoretically, at least, this dependence can give regulators an incentive to tread cautiously in enforcing regulation because actions, which threaten the economic viability of regulated businesses, also undermine the agency's financial position.

Light-handed regulatory systems often look to third parties to perform a monitoring role. However, the Tasmanian Forest Practices System largely precludes interest groups from fulfilling any sort of monitoring function. They have no formal role and struggle to access information. The Forest Practices Code requires that 'relevant information' contained in forest practice plans be made available to 'interested parties' but this vague provision does not ensure that detailed information was freely available. Although major players, Forestry Tasmania and Private Forests Tasmania, are publicly owned, they are largely sheltered from Freedom of Information requests under special provisions inserted into the State's Freedom of Information legislation in 1991 (Freedom of Information Act $1991 \mathrm{~s} 32 \mathrm{~A})$.

Access to plans is only one element of third party oversight. Others include the opportunity to verify the information contained in the plan, and capacity to observe operations. However, forestry 
activities invariably occur far from the public gaze and are further shielded from view by measures to protect the visual landscape. Such measures are necessary, according to Wilkinson (2003: 3-4), because a public, conditioned by instant television gardening, is ill equipped to understand and assess forestry operations.

The issue of transparency emerged in a 2002 review of the Tasmanian Regional Forest Agreement. The Review (Resource Planning and Development Commission 2002: 32-41) found that many aspects of the system worked well but identified considerable public disquiet due, in part, to a perceived lack of transparency, poor public understanding and inadequate communication between Board, industry and community. The Commonwealth, somewhat belatedly, perceived the credibility of the system was of 'paramount importance' and it insisted that changes be made to improve transparency and reliability (Australia 2004: 8).

In response, the Tasmanian Resources Minister Bryan Green announced changes to the Forest Practices System including reform of the Board, increased commitment to training, and repeal of the Freedom of Information protections for Forestry Tasmania. He declared the new Forest Practices Authority would 'include people with expertise in environmental or natural resource management, conservation, sustainable forest management, community liaison and local government'. In addition, the new Authority was to have an additional six new staff - four to monitor forestry operations and two to investigate breaches and improve public understanding of the system. Moreover, penalties would increase significantly - from $\$ 15,000$ to $\$ 100,000$ and the statute of limitations extended from one to three years (Green, 2004).

While these reforms may improve public perceptions, they do not appear to represent a major change to the existing system. For example, unless specifically excluded, industry stakeholders can easily be reappointed to the new authority given their areas of expertise. Any increase in penalties is only effective if it is accompanied by improved monitoring. While the system's monitoring capacity is to be expanded, it will still be modest given the scale of the industry. The effectiveness of the penalties will also depend on the authority's willingness to apply them and this would require considerable cultural change. Changes to Freedom of Information may go some way toward improving transparency on public land but do nothing to change the situation on private land. Fundamental elements, such as the status of Forest Practices Officers, limited avenues for public participation, and 'user pays' funding remain intact. The rhetoric of training based co-operation and continuous improvement remains, and there is no sign that the government is prepared to open the system up to 
include divergent voices. Indeed the changes themselves were the outcome of consultation with 'government, industry and the unions' (Green, 2004).

\section{Conclusion}

In its design of its Forest Practices System, the Tasmanian government opted for a light-handed regulatory approach. It argued that such an approach was necessary because of significant information asymmetry and an established culture of resistance, and contended that industry engagement and training within a co-operative framework had the capacity to deliver ecologically sustainable outcomes. However, this defence of the light-handed approach is built, to some extent, on an artifice of modern public management. Much of Tasmania's logging occurs not on private property, but in state forests. While the work may be done by independent contractors, the contracts are negotiated with and overseen by public employees. That Forestry Tasmania is run as a commercial enterprise, at arms length from government, is a choice made by government, albeit a choice shaped by other policy commitments such as National Competition Policy. These structural choices, however, should not disguise that fact that government retains significant capacity to control its own activities. The Tasmanian government's application of a light-handed approach to its own instrumentality is more a product of policy choice than industry structure and culture. Tougher rules would put Forestry Tasmania at a competitive disadvantage vis-à-vis other industry players and undermine its economic viability, an unwelcome prospect for a government committed to logging.

This observation aside, we still need to assess the Forest Practices System in relation to logging on private land where the rationale of industry characteristics holds true. Regulatory reformers argue that light-handed or responsive regulation offers a way of overcoming the shortcomings of traditional command and control approaches because it recognizes factors which drive business - a tendency to be law abiding, to respond to economic incentives, and so on. It is most suited to situations where risk is low, interests coincide, and third party oversight is possible. In the environmental context, Gunningham and Grabosky (1997: 290) note that these conditions are most commonly met in urban, industrial contexts and less likely to be found in agricultural situations. In the logging industry, although the cultural and informational variables might suit light-handed regulation, others, such as the nature of the problem, the structure of industry, and most importantly, the capacity for third party oversight, point to the opposite. Light-handed regulation is less applicable to an industry characterised by a large numbers of small players, dealing with a problem characterised by contested levels of risk, and providing only limited opportunities for third party oversight. The recently 
announced reforms may go some way to strengthening the system although according to a recent commentator, '[the] proof of the pudding is in the eating' (Eastment 2004).

This paper has focused on one regulatory approach, one element of the regulatory mix and found it wanting. Perhaps other elements of the mix, such as genuinely self regulatory mechanisms such as ISO14001 or Forest Stewardship Certification offer a way forward in a situation where government remains committed to its current approach. However, consideration of such mechanisms, either as alternatives or complements, is beyond the scope of this paper.

\section{References}

Australia, Treasurer 2004. Australian government response Tasmanian Resource Planning and Development Commission inquiry on the progress with implementation of the Tasmanian regional forest agreement (1997), Treasurer, Canberra, 10 August. viewed 11 September 2004. $<$ http://www.treasurer.gov.au/tsr/content/publications/pub_downloads/066_Government_res ponse.pdf>.

Australian Bureau of Statistics)2004. Statistics - Tasmania, Forestry, Private forestry, Australian Bureau of Statistics, Canberra. viewed 11 September 2004.

<http://www.abs.gov.au/Ausstats/abs@.nsf/94713ad445ff1425ca25682000192af2/60aa9536e142 0e08ca256c320024162a!OpenDocument>

Ayres, I. and Braithwaite, J. 1992. Responsive Regulation. Oxford University Press, New York.

Baldwin, R., Scott, C. and Hood, C. 1998. Introduction. In: Baldwin, R., Scott, C. and Hood, C. (eds) A Reader on Regulation, pp.1-36. Oxford University Press, Oxford.

Beierle, T.C. and Cayford, J. 2002. Democracy in Practice: Public Participation in Environmental Decisions. Resources for the Future, Washington.

Carmin, J., Darnall, N. and Mil-Homens, J. 2003. Stakeholder involvement in the design of U.S. Voluntary Environmental Programs: does sponsorship matter? Policy Studies Journal, 31(4): 527-543.

Daneke, G.A. 2001. Sustainable development as systemic choices Policy Studies Journal, 29 (3): 514-533.

Darby, A.2003. 'Giant tree damaged during burn-off', The Age, 1 May, p.3.

Eastment, R. 2004. Interview with A. Guest, World Today, ABC Radio, broadcast 31 Aug.

Eisner, M.A. 2003 Regulatory Politics in Transition. John Hopkins University Press, Baltimore.

Fiorino, D.J. 2001. Environmental policy as learning: a new view of an old landscape. Public Administration Review, 61(3): 322-334.

Freedom of Information Act 1991 Tasmania

Forest Enterprises Ltd 2004. Business built on strategic expansion, Forest Enterprises Ltd, Launceston. viewed 11 September 2004. <http://www.forestenterprise.com/section.asp?id=10\&secid=7>

Forest Practices Act; 1985 Tasmania.

Forest Practices Board 2000. Forest Practices Code. Forest Practices Board Tasmania, Hobart.

Forest Practices Board Tasmania 2002. Draft forest practices code 2000 summary of comments received and response by the Forest Practices Board, Forest Practices Board Tasmania, 
Hobart. viewed 16 September 2004.

$<$ http://www.fpb.tas.gov.au/pdf_files/Summ_Review_FPC2000.pdf $>$.

Forest Practices Board Tasmania 2003. Annual Report 2002/3. Forest Practices Board Tasmania, Hobart.

Forest Practices Board Tasmania 2004. Annual Report 2003/4. Forest Practices Board Tasmania, Hobart.

Forestry Tasmania, 2002. Giant Trees Policy Forestry Tasmania, August. viewed 7 July 2005. $<\mathrm{http}$ ://www.forestrytas.com.au/forestrytas/pdf_files/giant_trees_policy.pdf >

Francis, J. 1993. The Politics of Regulation A Comparative Perspective. Blackwell, Oxford.

Green, B. 2004. Overhaul for forest practices system. media release 30 Aug.

Gunningham N. and Grabosky, P. with Sinclair, D. 1998. Smart Regulation Designing Regulatory Policy. Clarendon, Oxford.

Gunningham, N. and Rees, J. 1997. Industry self-regulation. Law and Policy 19(4): 363-414.

Gunningham, N. and Sinclair, D. 2002. Leaders or Laggards next generation environmental regulation, Greenleaf Publishing, Sheffield.

Halligan, J. and Wettenhall, R. 1990. Major changes in the structure of government institutions. In: Poert, J. (ed.) Public Administration in Australia: a watershed, pp. 17-40. Hale and Iremonger, Sydney.

Hill, L. and Stewart, L. 'Responsive regulation' theory and the sale of liquor act (1). Social Policy Journal of New Zealand, December: 49-60.

Independent Expert Advisory Group 1997. Assessment of Ecologically Sustainable Forest Management Systems and Processes - Final Report, report to the Joint Tasmania-Commonwealth Regional Forest Agreement Steering Committee. viewed 16 September 2004. $<$ http://www.affa.gov.au/content/output.cfm?ObjectID=D2C48F86-BA1A-11A1A2200060B0A02682 >.

Jackson, N. 1997. Academic Regulation in UK Higher Education: part 1. Quality Assurance in Higher Education, 5(3): 120-135.

McDonald, G.T. and Lane, M.B. 2002. Forest management systems evaluation: using ISO14000. Journal of Environmental Planning and Management, 45(5): 633-652.

Mitnick, B. M. 1980. The Political Economy of Regulation Creating, Designing, and Removing Regulatory Forms. Columbia University Press, New York.

Moran, M. 2001. Not steering but drowning: policy catastrophes and the regulatory state. The Political Quarterley, 72(4): pp.414427.

Moran, M. 2002. Understanding the Regulatory State. British Journal of Political Science, 32(2):391-413.

National Competition Council 1998. Compendium of National Competition Policy Agreements, $2^{\text {nd }}$ ed. AGPS, Melbourne.

Ogus, A. 1994. Regulation : legal form and economic theory. Clarendon Press, Oxford.

Ogus, A. 1995. Rethinking self-regulation. Oxford Journal of Legal Studies, 15(1): 97-108.

Paine, Michelle 2003. Giant tree 'cooked to death', The Mercury 3 May, p. 3.

Legislative Assembly, Parliament of Tasmania, 1999. Forest Practices Amendment Bill debate 25 March part 2: 40-107.

Resource Planning and Development Commission 2002 Inquiry on the Progress with Implementation of the Tasmanian Regional Forest Agreement (1997) Final Recommendations Report, Resource Planning and Development Commission Tasmania, Hobart.

Seidenfeld, M. 2000. Empowering stakeholders; limits on collaboration as the basis for flexible regulation. William and Mary Law Review, 41(2): 411-502. 
Senate, Parliament of Australia, Rural and Regional Affairs and Transport Legislation Committee 2004. A Review of Plantations for Australia: The 2020 Vision, Commonwealth of Australia, Canberra.

Sharp, J. 1996. Entrepreneurship and regulatory integrity. In: Wanna, J., Forster, J. and Graham, P. (eds) Entrepreneurial Management in the Public Sector, pp. 243-251, Macmillan, South Melbourne.

Sinclair, D. 1997. Self-regulation versus command and control? Law and Policy 19(4): 529-559.

Sparrow, M.K. 2000. The Regulatory Craft. Brooking Institution Press, Washington D.C.

Weber, E.P. 1998. Successful collaboration: negotiating effective regulation. Environment 40(9): 10-22.

Wilkinson, G. R. 1999. Codes of forest practice as regulatory tools for sustainable forest management. 18th Biennial Conference of the Institute of Foresters of Australia, 3-8 October. Hobart.

Wilkinson, G.R. 2001. Building partnerships - Tasmania's approach to sustainable forest management. In: International Conference on the Application of Reduced Impact Logging to Advance Sustainable Forest Management: Constraints, Challenges and Opportunities, 26 February - 1 March, Kuching, Sarawak, Malaysia. Compendium of Conference papers: 219226.

Wilkinson, G.R. 2003. Landscape what you see is what you get. Forest Practices News 5(2) pp. 3-4. 